Nama : Audhatul faidz

NIM : 10200120220

Kelas : HTN-F

\title{
RESUME PARTAI POLITIK DAN PEMILIHAN UMUM
}

Partai politik merupakan organisasi yang bersifat nasional yang dibentuk oleh sekelompok warga negara dengan sukarela. Karna ada tujuan membela dan memperjuangkan tujuan yang sama (UU RI No.2 Tahun 2008 tentang partai politik). Sedangkan pemilihan umum atau pemilu adalah suatu proses untuk memilih suatu anggota partai politik yang berhak untuk menduduki jabatan jabatan tertentu. Dan partai politik merupakan satu satunya partai yang berkaitan dengan pemilu dimusim pemilihan umum partai politik bertigas menutupi kelemhannya dengan cara menguatkan identitas partainya agar menarik simpatik masyarakat untuk memilih kandidat dari partai tersebut.

Keberadaan partai politik merupakan sesuatu yang tidak bisa dielakkan dalam sebuah tatanan masyarakat modern dan berstruktur kompleks. Sebab partai politik dianggap mempunyai kemampuan untuk menyalurkan partisipasi politik masyarakat yang kompleks tersebut. Semakin kompleks sebuah masyarakat, maka keberadaan partai politik akan semakin diperlukan sebagai penyalur aspirasi dan penyalur partisipasi politik masyarakat. Tanpa adanya partai politik, kepentingan dan partisipasi politik rakyat akan kurang tersalurkan. Tujuan utama partai politik adalah untuk mendapatkan kekuasaan politik dan merebut kedudukan politik dengan cara konstitusional guna melaksanakan programnya. Dalam program tersebut salah satunya mengandung aspirasi yang berasal dari masyarakat.

Bagi negara penganut demokrasi, keberadaan partai politik merupakan hal yang lumrah. Sebab partai politik merupakan salah satu atribut dari sistem demokrasi itu sendiri. Meskipun tidak memiliki wewenang untuk merumuskan kebijakan publik, keberadaan partai politik tidak bisa dipandang sebelah mata. Kegiatan-kegiatan partai politik, baik secara langsung maupun tidak langsung dapat memengaruhi pemerintah selaku perumus utama kebijakan publik.

Fungsi partai politik dalam negara demokrasi, yaitu: Sarana sosialisasi politik Maksud fungsi partai politik sebagai sarana sosialiasi politik adalah partai politik berperan mentransmisikan budaya politik dalam rangka pembentukan sikap dan orientasi anggota masyarakat sebagai warga negara (pendidikan politik). 
Secara internal, rekrutmen politik berfungsi untuk memperoleh kader-kader yang berkualitas. Semakin banyak kader berkualitas yang diperoleh dari rekrutmen politik, maka akan semakin besar peluang dari partai politik tersebut untuk mengajukan calonnya dalam bursa kepemimpinan nasional. Sarana partisipasi politik Sebagai sarana partisipasi politik, partai politik menjadi sarana bagi masyarakat dalam memengaruhi proses pembentukan pemimpin pemerintahan melalui pemilu dan pembuatan atau pelaksanaan kebijakan pemerintah.

Pemilihan umum yang disingkat pemilu menjadi sangat dekat hubungannya dengan masalah politik dan pergantian pemimpin.Dilansir dari situs resmi Komisi Pemilihan Umum, dalam sebuah negara demokrasi, pemilu merupakan salah satu pilar utama dari proses akumulasi kehendak masyarakat. Pemilu sekaligus merupakan proses demokrasi untuk memilih pemimpin.

Pengertian pemilu Sesuai Undang-undang Nomor 8 Tahun 2012 Tentang Pemilihan Umum Anggota Dewan Perwakilan Rakyat, Dewan Perwakilan Daerah dan Dewan Perwakilan Rakyat Daerah pengertian pemilihan umum diuraikan secara detail. Pemilu adalah sarana pelaksanaan kedaulatan rakyat yang dilaksanakan secara langsung, umum, bebas, rahasia, jujur, dan adil dalam Negara Kesatuan Indonesia berdasarkan Pancasila dan Undang-undang Dasar Negara Republik Indonesia 1945. Dengan kata lain, pemilu merupakan sarana bagi rakyat untuk menjalankan kedaulatan dan merupakan lembaga demokrasi.

Pemilu sebenarnya memiliki empat fungsi utama, yaitu:

1.Pembentukan legitimasi penguasa dan pemerintah

2.Pembentukan perwakilan politik rakyat

3.Sirkulasi elite penguasa

4.Pendidikan politik

Dalam pelaksanaannya pemilu memiliki tujuan yaitu : Pemilu sebagai implementasi kedaulatan rakyat Kedaulatan terletak di tangan rakyat. Hal ini karena rakyat yang berdaulat tidak bisa memerintah secara langsung. Dengan pemilu, rakyat dapat menentukan wakilwakilnya. Para wakil terpilih juga akan menentukan siapa yang akan memegang tampuk pemerintahan, Pemilu sebagai sarana membentuk perwakilan politik Melalui pemilu, rakyat dapat memilih wakil-wakil yang dipercaya untuk menyalurkan aspirasi dan kepentingannya. Semakin tinggi kualitas pemilu, semakin baik pula kualitas para wakil rakyat yang bisa terpilih dalam lembaga perwakilan rakyat, Pemilu sebagai sarana penggantian pemimpin secara konstitusional Pemilu bisa mengukuhkan pemerintahan yang sedang berjalan atau untuk mewujudkan reformasi pemerintahan. 
Dari definisi dan tujuan serta fungsi dari partai politik maka dapat dirumuskan secara umum, bahwa tugas dari partai politik adalah sebagai mediator antara rakyat dengan pemerintah, dan juga sebaliknya. Secara khusus tugas partai politik akan dijabarkan di bawah ini.

Mengajak masyarakat untuk berpartisi dalam sebuah keputusan politik, dan mewujudkan pendapat pendapat partai politik menjadi sebuah kebijakan bagi seluruh rakyat.

Melakukan proses peyeimbangan pendapat agar tidak terjadi suatu perpecahan dalam sebuah negara, dan membentuknya menjadi kebijakan bersama yang dapat diterima oleh seluruh masyarakat.

Melakukan proses penyampaian aspirasi rakyat kepada pemerintah, demi mewujudkan pemerintahan dengan sistem yang lebih baik.

Melakukan kegiatan perekrutan, dan melatih para kandidat yang nantinya akan ditunjuk sebagai orang yang menjabat di kursi pemerintahan.

Dalam menjalankan tugas tugas tersebut partai dijamin atau dilindungi oleh beberapa undang undang seperti dibawah ini:

\section{Berhak berorganisasi secara bebas}

Diberi suatu hak untuk bebas mencalonkan diri sebagai wakil rakyat di pemilihan umum Mempunyai kebebasan untuk berbicara, berpendapat, dan berkumpul.

Adanya kebebasan dalam menentukan cara mainnya, dan dilindungi dari tindak tindak diskriminasi

Diberikan akses media dan tindakan pelaporan yang adil

Disediakan sebuah lahan kompetisi yang adil dan juga damai antara satu partai dengan partai lainnya, atau antara satu kandidat dengan kandidat yang lainnya Partai Politik di Indonesia

Partai politik di Indonesia sangat banyak dan mempunyai ideologi dasar yang berbeda beda. Ternyata tidak semua partai dapat lolos untuk menjadi peserta sebuah pemilihan umum. Partai yang boleh ikut adalah partai yang sudah lolos syarat administratif, dan lolos verifikasi secara faktual yang bersifat nasional. 
Syarat administrasi dan verifikatif yang harus dipenuhi untuk lolos sebagai partai peserta pemilu adalah adanya anggota yang bertugas sebagai pengurus suatu partai politik di tingkat pusat pemerintahan, dan adanya wakil perempuan minimal sebanyak 30 persen, dan adanya kantor tetap yang berdomisili di tingkat DPP.

Syarat selanjutnya adalah adanya pengurus partai yang tersebar minimal di lima puluh persen kecamatan pada tujuh puluh lima persen Kota ataupun Kabupaten di tiga puluh empat provinsi. Syarat lainnya adalah memenuhi jumlah keanggotaan di tujuh puluh lima persen Kota ataupun Kabupaten dari 34 provinsi.

Untuk partai peserta pemilu tahun 2019 sendiri sudah ditentukan sejumlah 14 partai, dan ada dua partai yang tidak lolos seleksi, dari total 16 kontestan pada mulanya. Berikut ini adalah partai peserta pemilu 2019. Pemilihan Umum Indonesia 1955 adalah pemilihan umum pertama dilndonesia dan diadakan pada tahun 1955. Pemilu ini sering dikatakan sebagai pemilu Indonesia yang paling demokratis.

Pemilu tahun 1955 ini dilaksanakan saat keamanan negara masih kurang kondusif, beberapa daerah dirundung kekacauan oleh DI/TII (Darul Islam/Tentara Islam Indonesia) khususnya pimpinan Kartosuwiryo. Dalam keadaan seperti ini, anggota angkatan bersenjata dan polisi juga memilih. Mereka yang bertugas di daerah rawan digilir datang ke tempat pemilihan. Pemilu akhirnya pun berlangsung aman.

Pemilu ini bertujuan untuk memilih anggota-anggota DPR dan Konstituante. Jumlah kursi DPR yang diperebutkan berjumlah 260, sedangkan kursi Konstituante berjumlah 520 (dua kali lipat kursi DPR) ditambah 14 wakil golongan minoritas yang diangkat pemerintah.

\section{FUNGSI SISTEM PEMILIHAN UMUM ANGGOTA DPR DAN DPRD}

Setidak-tidaknya terdapat dua fungsi sistem pemilihan umum. Pertama, sebagai prosedur dan mekanisme konversi suara pemilih (votes) menjadi kursi (seats) penyelenggara negara lembaga legislatif dan/atau lembaga eksekutif baik pada tingkat nasional maupun lokal. 
Prosedur dan mekanisme seperti inilah yang biasa disebut proses penyelenggaan tahapan Pemilu. Untuk membedakan Pemilu authoritarian dari Pemilu demokratik, maka negara demokrasi menyusun undang-undang tentang pemilihan umum yang pada dasarnya merupakan penjabaran prinsip-prinsip demokrasi. Dari undang-undang Pemilu yang berisi penjabaran prinsip-prinsip demokrasi, seperti asas-asas Pemilu, Pemilu Berintegritas, dan Pemilu Berkeadilan, akan dapat dirumuskan sejumlah parameter untuk proses penyelenggaraan Pemilu yang demokratik. Dan kedua, sebagai instrumen untuk membangun sistem politik demokrasi, yaitu melalui konsekuensi setiap unsur sistem pemilihan umum terhadap berbagai aspek sistem politik demokrasi. Sistem Pemilu terdiri atas enam unsur, dan empat diantaranya merupakan unsur mutlak dan dua unsur pilihan. Keempat unsur mutlak tersebut adalah Besaran Daerah Pemilihan, Peserta dan Pola Pencalonan, Model Penyuaraan, dan Formula Pemilihan. Keempatnya disebut sebagai unsur mutlak karena tanpa salah satu dari keempat unsur ini ketiga unsur lain tidak akan mampu mengkonversi suara pemilih menjadi kursi. Dua unsur pilihan, yaitu ambang-batas perwakilan dan waktu penyelenggaraan berbagai jenis Pemilu, dikategorikan sebagai pilihan karena (1) keempat unsur sistem pemilihan umum lainnya masih mampu mengkonversi suara pemilih menjadi kursi, dan (2) salah satu atau keduanya akan digunakan untuk mencapa tujuan lain yang tidak dapat dicapai dengan unsur sistem pemilihan umum lainnya.Setiap unsur sistem pemilihan umum terdapat sejumlah pilihan, dan setiap pilihan memiliki konsekuensi terhadap berbagai aspek sistem politik demokrasi. Misalnya, Besaran Daerah Pemilihan terdiri atas dua ukuran, yaitu satu kursi per Dapil (single-member constituency), dan banyak kursi per Dapil (multi-members constituency). Banyak kursi per Dapil dapat dibedakan menjadi tiga ukuran, yaitu Dapil Kecil 2 sampai dengan 5 kursi (Small Constituency), Dapil Sedang 6 sampai 9 kursi (Medium Constituency), dan Dapil Besar 10 atau lebih (Large Constituency). Termasuk yang terakhir ini adalah Dapil Tunggal secara Nasional (singlenation constituency), seperti yang diterapkan Negeri Belanda dan Timor Leste. Dengan kata lain, terdapat 5 pilihan untuk Besaran Daerah Pemilihan dan yang masing-masing memiliki konsekuensi terhadap sistem kepartaian ataupun sistem perwakilan politik.Proses pembuatan undang-undang Pemilu oleh DPR dan Pemerintah selama ini cenderung tidak memperlakukan sistem pemilihan umum secara komprehensif. Proses penyelenggaraan Pemilu tidak disusun berdasarkan parameter Pemilu yang jelas. Satu-satunya tahap yang diatur dengan prinsip yang jelas adalah pemungutan dan penghitungan suara di TPS . Prinsip yang mengatur proses pemungutan dan penghitungan suara di TPS tidak hanya enam asas Pemilu yang disebutkan dalam Pasal 22E ayat (1) UUD 1945, yaitu langsung, umum, bebas, rahasia, jujur dan adil, tetapi juga dua asas tambahan, yaitu transparan dan akuntabel. UU Pemilu mengatur soal kampanye dan dana kampanye Pemilu beserta larangan dan sanksinya. Akan tetapi karena dirumuskan tidak berdasarkan parameter Pemilu demokratik yang jelas, maka tidak hanya ketentuan tentang kampanye dan dana kampanye banyak mengandung kekosongan hukum tetapi juga mekanisme penegakan ketentuan tersebut. Lain halnya bila ketentuan kampanye dan dana kampanye tersebut 
berdasarkan parameter yang jelas, seperti 'persaingan yang bebas dan adil antar peserta Pemilu untuk meyakinkan pemilih agar memberikan suara kepada mereka,' akan dapat disusun ketentuan, larangan, sanksi dan mekanisme penegakan hukum yang tepat. Contoh lain alokasi 560 kursi DPR kepada provinsi seluruh Indonesia yang dijadikan sebagai Lampiran UU Nomor 8 Tahun 2012. Alokasi kursi ini merupakan 'alokasi kursi DPR kepada provinsi pada Pemilu 2004 yang disesuaikan baik karena penambahan 10 kursi DPR maupun karena pembentukan Daerah Otonom Baru. Kursi DPR ini dialokasikan kepada setiap provinsi tanpa kriteria yang jelas. Pada hal alokasi kursi DPR kepada setiap provinsi seharusnya dilakukan berdasarkan prinsip kesetaraan antar warga negara (equal representation): satu orang, satu suara, dan nilai setara. Karena alokasi kursi tanpa parameter yang jelas, maka harga (jumlah penduduk) satu kursi DPR yang paling tinggi dan harga kursi paling rendah tidak terletak di Jawa melainkan di Luar Pulau Jawa (Kep. Riau dan Papua Barat). Bahkan provinsi yang over representation (mendapat kursi terlalu banyak bila dibandingkan dengan jumlah penduduknya) dan under representation (menerima kursi terlalu sedikit bila dibandingkan dengan jumlah penduduknya) keduanya terletak di Luar Pulau Jawa. Karena pembentukan daerah pemilihan berupa penggabungan beberapa wilayah dilakukan tanpa kriteria dan persyaratan yang jelas, maka terjadilah pembentukan Dapil DPR yang paling aneh di dunia, yaitu penggabungan dua wilayah melompati wilayah lain (seperti penggabungan Kota Bogor dengan Kabupaten Cianjur melompati Kabupaten Bogor). 
